\title{
Tuberkulosis Perinatal Bermanifestasi sebagai Tuberkulosis Milier dan Meningitis
}

\author{
Heda Melinda D. Nataprawira, Faisal \\ Bagian Ilmu Kesehatan Anak \\ Fakultas Kedokteran Universitas Padjadajaran \\ Rumah Sakit Hasan Sadikin, Bandung
}

\begin{abstract}
Abstrak
Tuberkulosis (TB) perinatal adalah kasus TB yang jarang dilaporkan karena manifestasi klinis tidak spesifik, serta terdapat permasalahan dalam pemeriksaan laboratorium dan radiologis sehingga tidak terdiagnosis. Istilah TB perinatal menjelaskan adanya infeksi Mycobacterium tuberculosis yang terjadi pada masa perinatal baik selama kehamilan, persalinan, maupun pascapersalinan dalam masa neonatus. Seorang bayi laki-laki usia tiga bulan dirujuk ke Emergensi Anak Rumah Sakit Hasan Sadikin dengan riwayat demam lama dan tidak mau menetek. Proses kelahiran tidak ada masalah. Pada pemeriksaan fisis ditemukan letargis, febris, takipnea, dan hepatosplenomegali. Pewarnaan Ziehl Neelsen aspirat lambung menunjukkan basil tahan asam positif. Uji kulit tuberkulin menunjukkan nonreaktif, foto toraks memperlihatkan gambaran milier, dan fungsi lumbal memberikan interpretasi TB meningitis. Berdasarkan penelusuran aktif sumber penularan TB serumah, ternyata ayah dan kakek bayi merupakan sumber penularan. Selain diberikan paduan oral antituberkulosis standar, juga diberikan antibiotik dan prednison. Dalam perjalanan penyakitnya, terjadi syok sepsis serta koagulasi intravaskular diseminata dan bayi meninggal. Dari kultur darah teridentifikasi Staphylococcus haemolyticus. Disimpulkan bahwa walaupun tidak terdapat permasalahan saat kelahiran bayi, diperlukan penelusuran aktif kemungkinan TB perinatal pada keluarga dengan sumber penularan TB positif. Diperlukan kewaspadaan terdapatnya TB pada wanita hamil di negara berkembang dengan jumlah kasus TB tinggi. [MKB. 2010;42(3):135-9].
\end{abstract}

Kata kunci: Koagulasi intravaskular diseminata, milier, meningitis, tuberkulosis perinatal

\section{Perinatal Tuberculosis Presenting as Miliary Tuberculosis and Meningitis}

\begin{abstract}
Perinatal tuberculosis (TB) is rarely reported, because the clinical manifestations are not specific and there is a problem in its laboratory and radiology examination which caused undiagnosed. Perinatal TB is the preferred description that encompasses TB acquired either intra uterine, during or post delivery in early newborn period. A-3month old baby was transferred to Pediatric Emergency Hasan Sadikin Hospital because of prolong fever and unable to breastfeed. There was no problem with delivery. Lethargic, fever, tachypnea, and hepatosphlenomegali were found on physical examination. Ziehl Neelsen smear of gastric lavage yielded positive acid fast bacilli. Tuberculine test was non reactive, chest x-ray showed a miliary pattern, and cerebral spinal fluid analysis gave tuberculous meningitis interpretation. By active finding, his father and grandfather were detected as a source of TB transmission. In additon to oral antituberculosis regimen, antibiotics and prednison were also given. Septic shock and disseminated intravascular coagulation were occurred during his illness and the baby died. Staphylococcus haemolyticus was identified from blood culture. In conclusion, although there were no problems during labor, active investigation of perinatal TB possibility is required on the family with a source of TB. Caution on TB in pregnant women is necessary at developing country with high rates of TB. [MKB. 2010;42(3):135-9].
\end{abstract}

Key words: Disseminated intravascular coagulation, miliary, meningitis, perinatal tuberculosis

Korepondensi: dr. Heda Melinda, Sp.A(K)., Bagian Ilmu Kesehatan Anak, Fakultas Kedokteran Universitas Padjadjaran, Rumah Sakit Hasan Sadikin, jalan Pasteur 38 Bandung 40161, telepon (022) 2034426 


\section{Pendahuluan}

Tuberkulosis (TB) perinatal merupakan kasus yang jarang dilaporkan dengan angka kematian yang tinggi. Tuberkulosis perinatal digunakan untuk menjelaskan infeksi M. tuberculosis (M. tb) yang terjadi pada masa perinatal, penyebarannya dapat terjadi baik saat dalam kandungan (in utero), persalinan, maupun pascapersalinan. ${ }^{1}$ Pada awalnya TB perinatal dikenal dengan istilah TB kongenital. ${ }^{1}$ Istilah TB perinatal dan kongenital hanya untuk kepentingan epidemiologis, karena gejala klinis, penanganan, maupun prognosisnya sama. ${ }^{1,2}$

Menurut World Health Organization (WHO), TB merupakan masalah kesehatan masyarakat yang serius dengan $\pm 8,8$ juta kasus baru terjadi pada segala usia pada tahun 2003. Kasus yang meningkat ini akan berdampak pada peningkatan prevalensi TB pada wanita, termasuk ibu hamil. ${ }^{2}$ Apabila TB pada ibu hamil tidak dikenali dan ditangani dengan tatalaksana yang tepat maka kasus TB perinatal diperkirakan akan meningkat. ${ }^{3}$ Gejala, tanda, dan manifestasi klinis TB perinatal sulit diketahui, tetapi bila didiagnosis lebih dini, maka komplikasi TB perinatal yang lebih berat dapat dicegah., ${ }^{2,3}$

\section{Kasus}

Seorang bayi laki-laki usia tiga bulan dirujuk ke Emergensi Anak Rumah Sakit Hasan Sadikin oleh dokter spesialis anak dengan riwayat panas badan terus menerus sejak dua bulan dan hanya turun setelah diberikan obat penurun panas. Bayi sudah beberapa kali dibawa berobat. Perut bayi terlihat membesar sejak usia satu bulan. Bayi tidak mau menetek, gerakan kurang aktif, batuk, dan sesak napas sejak 7 hari sebelum masuk rumah sakit. Bayi tidak kejang, muntah, mencret, keluar cairan dari telinga, maupun penurunan kesadaran. Bayi dilahirkan dari ibu yang tidak mempunyai masalah selama masa kehamilan dan persalinan. Selama hamil ibu sehat dan kontrol teratur ke bidan. Berat badan lahir 3.200 gram dan tidak ada riwayat asfiksia. Setelah lahir bayi dapat menetek dengan kuat, tidak ada riwayat batuk, sesak napas, kejang, ataupun kuning. Berat badan naik menjadi 4.000 gram pada usia satu bulan namun kemudian berat badan turun menjadi 3.600 gram setelah penderita sering panas badan dan malas menetek.
Bayi belum dapat melakukan aktivitas sesuai dengan usianya. Bayi belum pernah mendapat vaksinasi apapun.

Pada pemeriksaan fisis didapatkan letargis, demam, dan sesak napas disertai peningkatan laju jantung. Perut bayi tampak cembung dan lembut, serta didapatkan hepatosplenomegali. Hipotoni ditemukan pada pemeriksaan neurologis. Pada pemeriksaan darah menunjukkan anemia ( $\mathrm{Hb} 8,6$ $\mathrm{g} / \mathrm{dL})$, serta jumlah leukosit $\left(6.800 / \mathrm{mm}^{3}\right)$ dan trombosit $\left(252.000 / \mathrm{mm}^{3}\right)$ dalam batas normal. Morfologi darah tepi menunjukkan gambaran hemolitik. Hasil SGOT, SGPT, serta bilirubin total dan direk dalam batas normal. Elektroforesis hemoglobin, urin, dan feses menunjukkan hasil normal. Pemeriksaan likuor serebrospinal ditemukan cairan tidak berwarna, jernih, jumlah sel $14 / \mathrm{mm}^{3}$ dengan dominasi monosit (58\%), glukosa $62 \mathrm{mg} / \mathrm{dL}$, protein $20 \mathrm{mg} / \mathrm{dL}$, sedangkan glukosa darah $104 \mathrm{mg} / \mathrm{dL}$. Basil tahan asam (BTA) tidak didapatkan pada likuor serebrospinal, sedangkan BTA positif didapatkan pada dua dari tiga pemeriksaan aspirat lambung. Foto toraks menunjukkan lesi diseminata berupa gambaran milier (Gambar 1). Pada pemeriksaan mata tidak ditemukan koroid tuberkel. Uji tuberkulin $0 \mathrm{~mm}$. Bayi mendapat obat antituberkulosis berupa paduan isoniazid, rifampisin, streptomisin dan pirazinamid, serta ditambah prednison $1 \mathrm{mg} / \mathrm{kg}$ berat badan. Bayi juga memperoleh antibiotik karena keadaan sakit bertambah berat. Selama perawatan menunjukkan perburukan beberapa hasil pemeriksaan darah, yaitu fibrinogen dari 105 menjadi 89,2 mg/dL, D-dimer 2,1 menjadi 3,1 mg/ $\mathrm{L}$, dan penurunan trombosit menjadi $35.000 / \mathrm{mm}^{3}$. Staphylococcus haemolyticus ditemukan pada kultur darah.

Penelusuran aktif penderita TB dewasa dilakukan untuk mengetahui sumber penularan yang diduga kontak dengan bayi. Kakek bayi telah meninggal karena sakit paru-paru. Penapisan TB paru dilakukan terhadap kedua orangtua bayi dengan pemeriksaan foto toraks. Ibu bayi berperawakan gemuk, sebelum dan selama hamil merasa sehat dan tidak pernah mengeluh batuk lama, berkeringat malam hari, berat badan menurun maupun kehilangan nafsu makan. Hasil pemeriksaan foto toraks tidak ditemukan TB paru (Gambar 2).

Ayah penderita tampak kurus dan didapatkan batuk lama lebih dari 6 bulan, sering berkeringat malam hari, nafsu makan berkurang, dan demam 


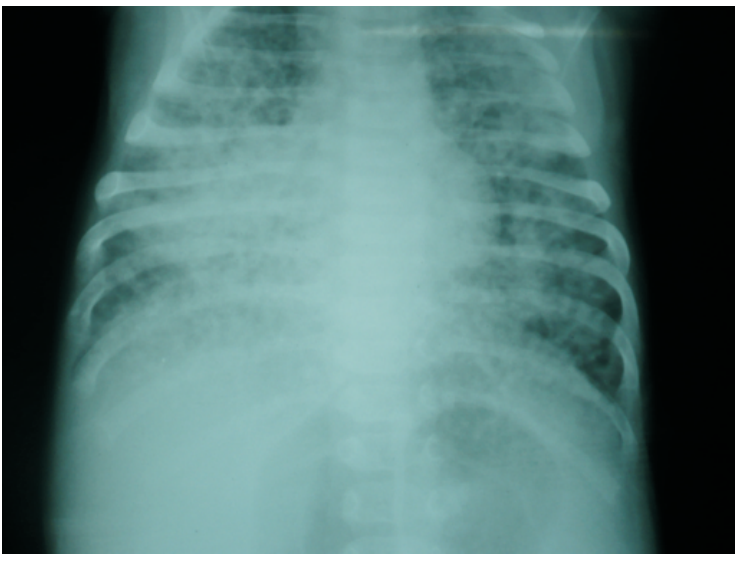

Gambar 1 Gambaran Milier pada Foto Toraks Penderita

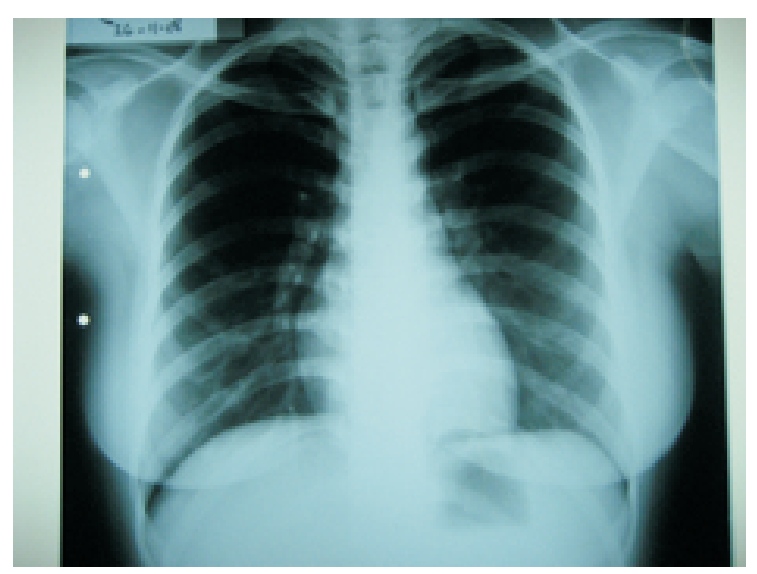

Gambar 2 Gambaran Foto Toraks Ibu Penderita: Tidak ditemukan TB

yang hilang timbul. Pada pemeriksaan foto toraks didapatkan kesan TB paru aktif(Gambar 3).

\section{Pembahasan}

Kasus TB perinatal dilaporkan pada tahun 1955 oleh Corner dan Brown, dikutip dari Laartz et $a l^{4}$ dengan jumlah kasus sebanyak 133 anak. Pada kepustakaan lain dilaporkan sampai tahun 1989 terdapat 300 kasus dan Abughali et al seperti dikutip de Souza et $a l^{5}$ melaporkan pada tahun 1994 sebanyak 58 kasus dan dari 2001 sampai 2005 terdapat 18 kasus dengan angka kematian yang sangat tinggi, berkisar 50-60\%. Jumlah yang dilaporkan ini sangat sedikit dibandingkan dengan insidensi yang sebenarnya karena banyak klinisi yang tidak mengenal bahkan dapat mendiagnosis

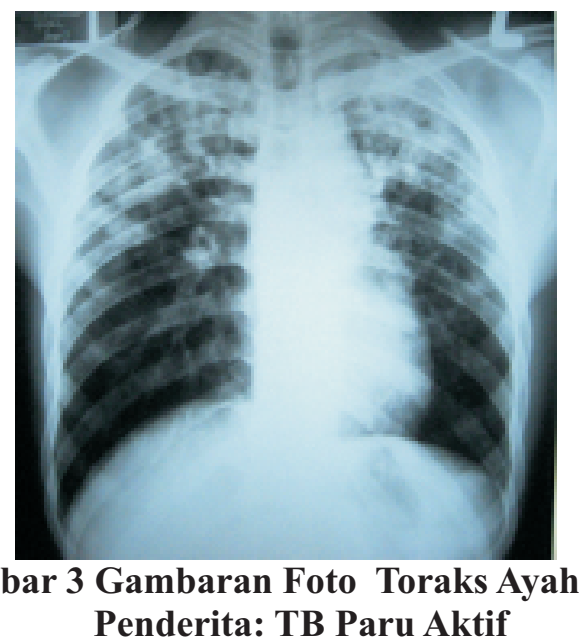

penyakit ini. Hal ini disebabkan manifestasi klinis TB yang tidak spesifik dan dapat menyerupai beberapa penyakit infeksi lain, misalnya sepsis, serta konfirmasi diagnosis TB sangat sulit pada anak terutama neonatus. Sebelum tahun 1950 penyakit ini selalu berakibat fatal pada bayi, tetapi setelah digunakan isoniazid sebagai salah satu obat TB pada tahun 1960-an, kasus TB perinatal yang berhasil ditangani semakin meningkat. ${ }^{1,4-6}$

Penularan TB perinatal dapat terjadi baik pada masa bayi di dalam kandungan (in utero), persalinan, maupun pascapersalinan. Walaupun terdapat perbedaan waktu penularan dari ibu kepada bayi, tetapi tidak ada perbedaan dalam hal gejala klinis, diagnostik, atau penatalaksanaan penyakit ini. Rute yang diyakini sebagai transmisi M. tb dari ibu hamil kepada bayi adalah secara hematogen dari lesi TB di plasenta ibu, aspirasi atau menelan cairan amnion yang terinfeksi M. tb, dan melalui droplet infection (infeksi percik renik) dari penderita TB dewasa setelah bayi lahir. ${ }^{2,5}$

Perbedaan antara TB perinatal dan kongenital adalah dalam kepentingan epidemiologis, sedangkan manifestasi klinis, penatalaksanaan, dan prognosisnya tidak berbeda. ${ }^{1,2}$ Gejala klinis TB kongenital dapat terlihat segera setelah bayi lahir, tetapi biasanya muncul pada usia minggu kedua atau ketiga dan biasanya tidak spesifik. Gejala ini menyerupai infeksi kongenital lain misalnya sifilis, herpes simpleks, toksoplasma, sitomegalovirus, atau sepsis bakterialis. Gejala klinis umum dapat bermanifestasi berupa distres pernapasan, letargis, demam, toleransi minum kurang baik, iritabel, distensi abdomen, gagal tumbuh dan kejang, sedangkan pada pemeriksaan 
fisis ditemukan adanya hepatomegali dan atau splenomegali, limfadenopati, ikterus, serta sekret dari telinga. ${ }^{2,-9}$ Gejala klinis TB kongenital dari 16 kasus pada penelitian Laartz et al. ${ }^{4}$ didapatkan distres pernapasan $(62,5 \%)$, hepatomegali dan atau splenomegali $(43,8 \%)$, demam $(43,8 \%)$, limfadenopati $(18,8 \%)$, sekret telinga $(12,5 \%)$, ruam $(6,3 \%)$, dan meningitis $(6,3 \%)$.

Pada kasus ini walaupun diagnosis ditegakkan di luar masa neonatus, tetapi diperkirakan bayi menderita TB perinatal. Hal ini didukung dengan terdapatnya manifestasi klinis yang sudah terjadi dalam bulan pertama kehidupan, pemeriksaan laboratorium, dan gambaran milier pada foto toraks. Pada kasus ini bayi kemungkinan besar mendapat penularan TB dari ayah dengan asumsi bahwa awitan gejala muncul pada usia sekitar satu bulan, mungkin hepatosplenomegali dan demam sudah terjadi sebelum usia satu bulan. Untuk menegakkan TB kongenital diperlukan beberapa kriteria yang diajukan oleh Cantwell et al., ${ }^{10}$ yaitu adanya bukti lesi TB pada bayi disertai lesi yang muncul pada minggu pertama setelah lahir, terdapat kompleks primer di hati, dan TB pada traktus genitalis atau plasenta ibu serta penularan pascakelahiran telah disingkirkan ${ }^{8,10-12}$ Pada kasus ini dugaan TB kongenital dapat disingkirkan karena tidak memenuhi kriteria TB kongenital, terutama adanya penularan setelah kelahiran yang harus dapat disingkirkan.

Pada bayi ini awitan gejala klinis didapatkan pada usia satu bulan dengan ditandai panas badan terus menerus disertai hepatosplenomegali, toleransi minum yang buruk, letargis, distres pernapasan, gagal tumbuh, serta meningitis. Meningitis ditandai adanya peningkatan jumlah sel pada pemeriksaan likuor serebrospinal yang menunjukkan adanya invasi $M$. tb ke susunan saraf pusat. Gejala lain, seperti limfadenopati, ruam, dan sekret dari telinga tidak didapatkan pada bayi ini. Hepatosplenomegali diyakini sebagai bagian dari TB karena hasil pemeriksaan elektroforesis hemoglobin tidak mendukung dugaan adanya thalassemia, demikian pula pemeriksaan SGOT, SGPT, serta bilirubin total dan direk dalam batas normal.

Pada pemeriksaan penunjang yang dilakukan, menunjukkan adanya BTA pada cairan aspirat lambung. Selain dari aspirat cairan lambung, BTA dapat diidentifikasi dari berbagai spesimen sesuai dengan penelitian Hageman, et al., yaitu dari autopsi, biopsi hati, biopsi nodul, sekret telinga, cairan serebrospinal, sekret endotrakeal, sumsum tulang, sekret nasofaring, atau urin. Pemeriksaan foto toraks menggambarkan TB milier yang merupakan gejala spesifik TB paru. Walaupun uji tuberkulin memberikan hasil negatif, tetapi hal ini tidak menyingkirkan adanya infeksi M. tb. Hal ini sesuai dengan penelitian Hageman et al. ${ }^{9}$ yang menyatakan bahwa sebagian besar uji tuberkulin pada TB perinatal adalah negatif. Uji tuberkulin tidak akurat pada bayi usia $<6$ bulan terutama bayi baru lahir karena sistem imun belum matur, tetapi uji ini tetap harus dilakukan pada bayi yang dicurigai mengidap TB kongenital atau perinatal.

Pada awalnya manifestasi klinis yang terjadi pada bayi ini menyerupai sepsis, seperti yang dilaporkan oleh Chanta et al. ${ }^{6}$ Selama perawatan, klinis dan kelainan hematologi memburuk, yaitu pemanjangan prothrombin time (PT), activated partial thromboplastine time (APTT), penurunan fibrinogen, serta peningkatan D-Dimer dengan didukung teridentifikasinya Staphylococcus haemolyticus pada kultur darah. Bayi meninggal pada minggu kedua perawatan karena terjadi komplikasi koagulasi intravaskular diseminata.

Walaupun tidak ditemukan permasalahan pada saat kelahiran bayi, tetapi adanya sumber penularan TB di dalam anggota keluarga yang teridentifikasi melalui penelusuran secara aktif, maka diperlukan pemantauan untuk kemungkinan terjadinya TB perinatal. Selain itu untuk negara berkembang dengan jumlah kasus TB tinggi, diperlukan kewaspadaan akan adanya TB pada wanita hamil.

\section{Daftar Pustaka}

1. Connell T, Bar-Zeev N, Curtis N. Early detection of perinatal tuberculosis using a whole blood interferon- release assay. Clin Infect Dis. 2006;42: 82-5.

2. Hammoud MS, Maiyegun SO, Al-Saban FM, Devarajan LV, Malik AH, Hanafi EM. Perinatally acquired tuberculosis in a neonate. Med Princ Pract. 2004;13:108-10.

3. Massik JS, Carrel T, Duppenthaler A, Zeilinger G, Gnehm HE. Congenital tuberculosis in a premature infant. Swiss Med Wkly. 2002:132: 598-602.

4. Laartz BW, Narvarte HJ, Holt D, Larkin JA, Pomputius WF. Congenital tuberculosis and management of exposure in a neonatal intensive care unit. Infect Control Hospital Epid. 2002;23 (10):573-9. 
5. de Souza EL, Moreira LM, Silva MF. Perinatal tuberculosis: a diagnostic challenge. Brazilian J Infec Dis. 2006;10:228-9.

6. Chanta C, Jariyapongpaibul Y, Triratanapa. Congenital tuberculosis presenting as sepsis syndrome. J Med Assoc Thai. 2004:187(5):573-9.

7. Tomar RPS, Gupta A, Prasad TR, Bhalla PJS, Murphy GSN. Congenital tuberculosis. MJAFI. 2008;64:78-80.

8. Chen A, Shih SL. Congenital tuberculosis in two infant. AJR. 2004;182:253-6.

9. Hageman J, Shulman S, Schreiber M, Luck S, Yogev R. Congenital tuberculosis: critical reappraisal of clinical findings and diagnostic procedures. Pediatrics. 1980;66(6):980-4.

10. Cantwell MF, Shehab ZM, Costello AM, Sands L. Congenital tuberculosis. N Engl J Med. 1994;330;1051-4.

11. Crockett M, King SM, Kitai I, Jamieson F, Richardson S, Malloy $\mathrm{P}$, et al. Nosocomial transmission of congenital tuberculosis in neonatal intensive care unit. Clin Infect Dis. 2004;39:1719-23.

12. Wong RMS, Wong KY, Lam BCC. Atypical presentation of congenital tuberculosis in a preterm infant. HK J Paediatr (new series). 2007; 12:133-6. 